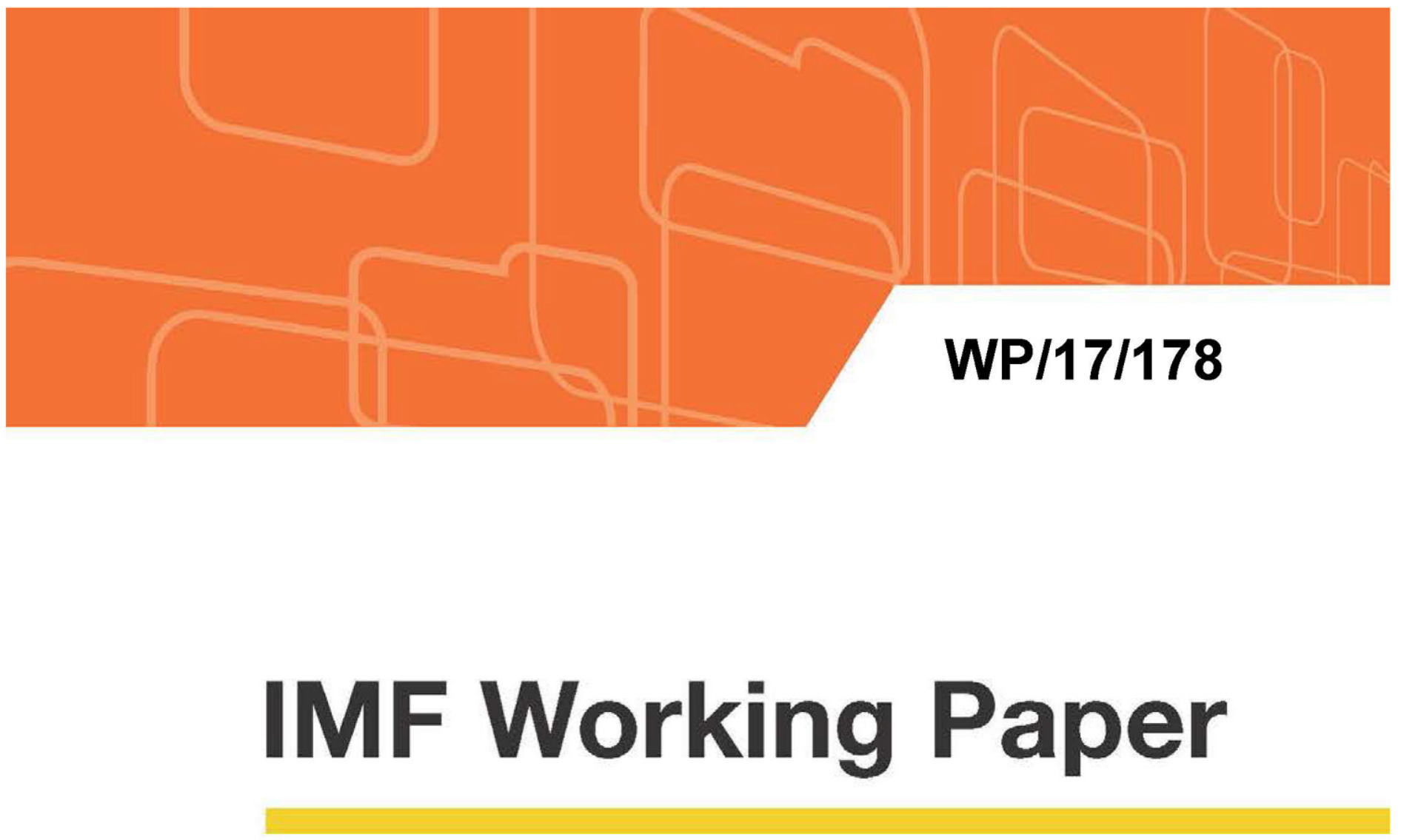

\title{
Calculating Trade in Value Added
}

by Aqib Aslam, Natalija Novta, and Fabiano Rodrigues-Bastos

IMF Working Papers describe research in progress by the author(s) and are published to elicit comments and to encourage debate. The views expressed in IMF Working Papers are those of the author(s) and do not necessarily represent the views of the IMF, its Executive Board, or IMF management. 


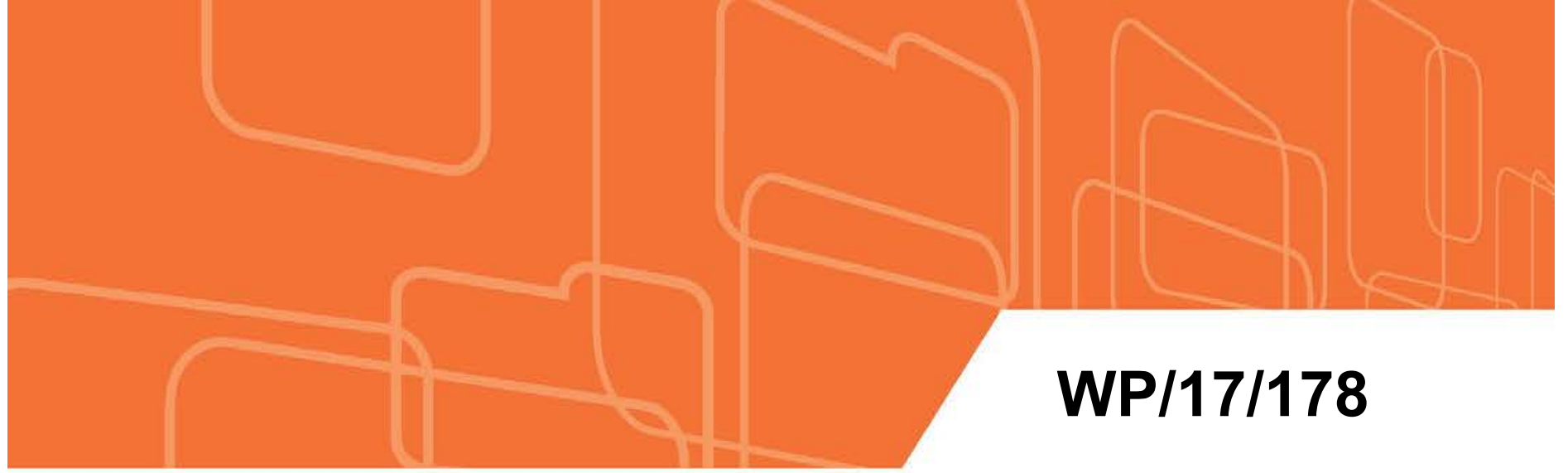

\section{IMF Working Paper}

\section{Calculating Trade in Value Added}

by Aqib Aslam, Natalija Novta, and Fabiano Rodrigues-Bastos

IMF Working Papers describe research in progress by the author(s) and are published to elicit comments and to encourage debate. The views expressed in IMF Working Papers are those of the author(s) and do not necessarily represent the views of the IMF, its Executive Board, or IMF management.

$$
\text { I N T E R N A T I O N A L M O N E T A R Y F U N D }
$$




\title{
IMF Working Paper
}

Research Department

\section{Calculating Trade in Value Added}

\section{Prepared by Aqib Aslam, Natalija Novta, and Fabiano Rodrigues-Bastos ${ }^{1}$}

Authorized for distribution by Oya Celasun

July 2017

\section{IMF Working Papers describe research in progress by the author(s) and are published to elicit comments and to encourage debate. The views expressed in IMF Working Papers are those of the author(s) and do not necessarily represent the views of the IMF, its Executive Board, or IMF management.}

\begin{abstract}
This paper sets out the key concepts necessary to calculate trade in value added using input-output tables. We explain the basic structure of an input-output table and the matrix algebra behind the computation of trade in value added statistics. Specifically, we compute measures of domestic value-added, foreign value added, and forward and backward linkages, as well as measures of both a country's participation and position in global value chains. We work in detail with an example of a global input-output table for 3 countries each with 4 sectors, provided by the Eora Multi-Region Input-Output (MRIO) database. The aim is to provide an introduction to the analysis of global value chains for use in policy work. An accompanying suite of Matlab codes are provided that can be used with the full set of Eora MRIO tables.
\end{abstract}

JEL Classification Numbers: F13, F15.

Keywords: Input-Output, Trade Integration, Trade in Value Added.

Author's E-Mail Address: aaslam@imf.org; nnovta@imf.org; fabianob@iadb.org.

\footnotetext{
${ }^{1}$ The authors are grateful to Diego Cerdeiro, Wenjie Chen, Marcello Estevao, Hamid Faruquee, Sergi Lanau, Andre Meier, Petia Topalova, for useful discussions and Steve Brito, Ava Yeabin Hong, and Hong Yang for excellent research assistance. All remaining errors are our own.
} 


\section{Contents}

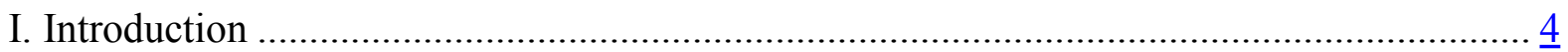

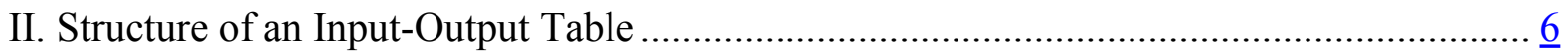

A. Calculating Gross Output and Exports....................................................................... 7

III. The Matrix Algebra of Input-Output Tables.................................................................. 2

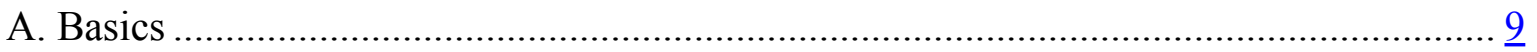

B. Calculating domestic and foreign value added …….............................................. 12

C. Detailed Decomposition of Gross Exports............................................................... 14

IV. Measures of Global Value Chain Participation ........................................................... 16

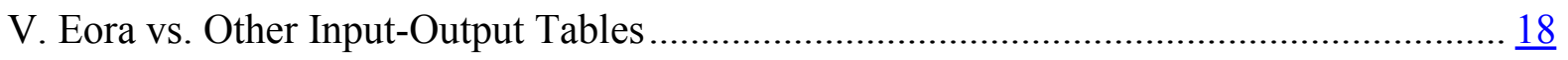

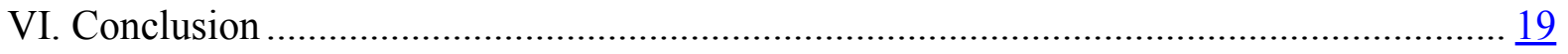

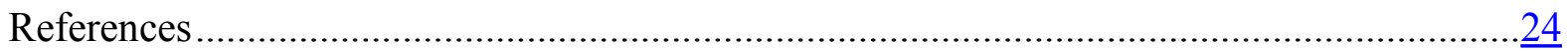

Figures

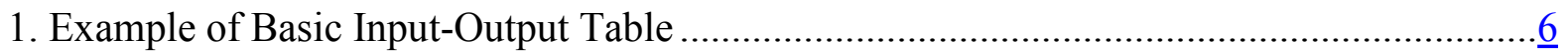

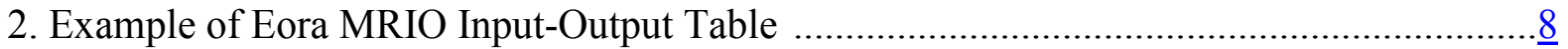

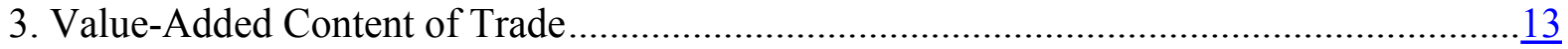

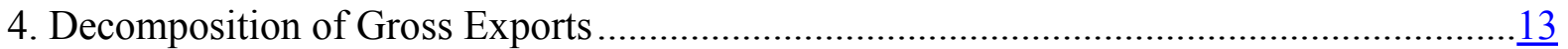

5. World Value-Added Exports by Country and Region..................................................... $\frac{15}{15}$

6. The Shifting Pattern of GVC Participation and Position..................................................

7. Comparing FVA from Eora and OECD-WTO Trade in Value-Added, 1995 ......................20

8. Comparing FVA from Eora and OECD-WTO Trade in Value-Added, 2000 ......................20

9. Comparing FVA from Eora and OECD-WTO Trade in Value-Added, 2005 ......................21

10. Comparing FVA from Eora and OECD-WTO Trade in Value-Added, 2008 .....................21

11. Comparing FVA from Eora and OECD-WTO Trade in Value-Added, 2009 .....................22

12. Comparing FVA from Eora and OECD-WTO Trade in Value-Added, 2010 .....................22

13. Comparing FVA from Eora and OECD-WTO Trade in Value-Added, 2011 .....................23

Table

1. Eora Sector Classification...................................................................................... 


\section{INTRODUCTION}

The global economy has become increasingly structured over time around global value chains (GVCs) that account for a rising share of international trade, global GDP, and employment. The core notion of GVCs is the location of different stages of the production process across multiple countries. Such production fragmentation means that intermediate goods cross borders several times along the chain, often passing through many countries more than once. The implication is that gross trade flows from traditional trade statistics no longer provide an adequate measure for understanding domestic value added and national income.

Global input-output tables can be used to derive data on the value added by each country in GVCs to get a clearer picture of trade flows related to activities of firms in GVCs. By providing a simple exposition of the design of input-output tables and the matrix algebra behind the computation of value-added trade, this note aims to serve as a basic user guide for how to integrate the analysis of GVCs into policy work. It provides formulae for some of the most common measures of GVC participation, as well as how to calculate a country's GVC position, providing examples of how such measures have changed over time for countries and regions. An accompanying MATLAB code also sets out how to compute measures for GVC participation using input-output tables.

The dataset used is the Eora Multi-Region Input-Output (MRIO) database (henceforth referred to as Eora (see Lenzen et al, 2012, and Lenzen et al, 2013). ${ }^{2}$ This dataset provides a set of both national and global input-output tables, covering 189 countries - 173 of which are included in the IMF's World Economic Outlook database - starting in 1990. Other inputoutput tables are also available but have either fewer countries or fewer years. Two of the most popular input-output tables are the OECD Inter-Country Input-Output (ICIO) tables and the World Input-Output Database (WIOD). The former covers the period 1995-2011 for 63 countries and 34 industrial sectors. While its coverage has been expanding recently, it is still considerably smaller than Eora - the years covered are 1995, 2000, 2005, and 2008 to 2011). The WIOD covers a similar period for 40 countries and 35 sectors. ${ }^{3}$ The Global Trade Analysis Project (GTAP) also produces input-output tables with wide country coverage, but

\footnotetext{
${ }^{2}$ The global Eora MRIO tables with a harmonized 26-sector classification across countries (also known as Eora26) can be accessed from http://worldmrio.com/simplified/. Please see the supporting documentation on the website for additional details.

${ }^{3}$ The 2016 release of the World Input-Output Tables covers 43 countries and 56 sectors.
} 
is only available for select years. ${ }^{4}$ Tukker and Dietzenbacher (2013) provide a more detailed overview of these different efforts to generate global input-output tables.

With 26 sectors Eora provides a relatively detailed sectoral classification, as listed in Table $1 .^{5}$ This sectoral classification is available in the "simplified Eora" data, and is consistent across all countries covered. In addition, for countries where more detailed classifications are available, more detailed input-output tables are also available. Given ease of use, as well as the need to compare across countries, we focus solely on the simplified Eora, with 26 sectors. ${ }^{6}$ Eora also provides the data using different prices - basic and purchaser's price. For most purposes, basic prices should be used.

\section{Table 1: Eora sector classification}

\begin{tabular}{clcl}
\hline Industry Code Sector Description & Industry Code & Sector Description \\
1 & Agriculture & 14 & Construction \\
2 & Fshing & 15 & Maintenance and Repair \\
3 & Mining and Quarrying & 16 & Wholesale Trade \\
4 & Food \& Beverages & 17 & Retail Trade \\
5 & Textiles and Wearing Apparel & 18 & Hotels and Restaurants \\
6 & Wood and Paper & 19 & Transport \\
7 & Petroleum, Chemical, and Non-Metallic Mineral Products & 20 & Post and Telecommunications \\
8 & Metal Products & 21 & Financial Intermediation and Business Activities \\
9 & Eectrical and Machinery & 22 & Public Administration \\
10 & Transport Equipment & 23 & Education, Health, and Oher Services \\
11 & Gher Manufacturing & 24 & Private Households \\
12 & Recycling & 25 & Ohers \\
13 & Eectricity, Gas, and Water & 26 & Re-export \& Re-import
\end{tabular}

Source: Eora MRODatabase (http://worldmrio.com/simplified/).

Eora data has already been successfully used by many researchers, including IMF (2016b), IMF (2015a), IMF (2015b), Cerdeiro (2016), Caliendo et al (2015), Feenstra (2017), as well as in the analysis of exchange rate pass through in IMF (2016a) and for understanding the role of GVCs in the recent global trade slowdown (IMF 2016b).

\footnotetext{
${ }^{4}$ Currently, the GTAP 9 database provides data for three reference years (2004, 2007, and 2011) for 140 regions and 57 sectors.

${ }^{5}$ There is also a mapping of these sectors to revision 3 of the standard industrial trade classification (SITC Rev.3). For more details, please contact authors.

${ }^{6}$ At the country level, to calculate value added in exports at the aggregate (i.e. not bilateral) level, we would recommend applying the methodology of Los et al. (2016) to more detailed national input-output tables (provided they are available).
} 


\section{Structure OF An InPUT-OUtPut TABle}

A simple example of an Input Output table is presented in Figure 1 below. In Figure 1, each country is assumed to have only one sector, called "industry". A more realistic example of the Eora input-output table is given in Figure 2. The example assumes a world made up of only 3 countries, each with 4 sectors and is used in the sample code below to calculate foreign value added (FVA) and domestic value added (DVA), as well as other concepts. The three key components (matrices) of an input-output table are:

1. Intermediate goods demand (the $\boldsymbol{T}$ matrix in Eora),

2. Final demand (the $\boldsymbol{F} \boldsymbol{D}$ matrix in Eora), and

3. Value added or primary inputs (the $\boldsymbol{V} \boldsymbol{A}$ matrix in Eora).

Figure 1. Example of Basic Input-Output Table

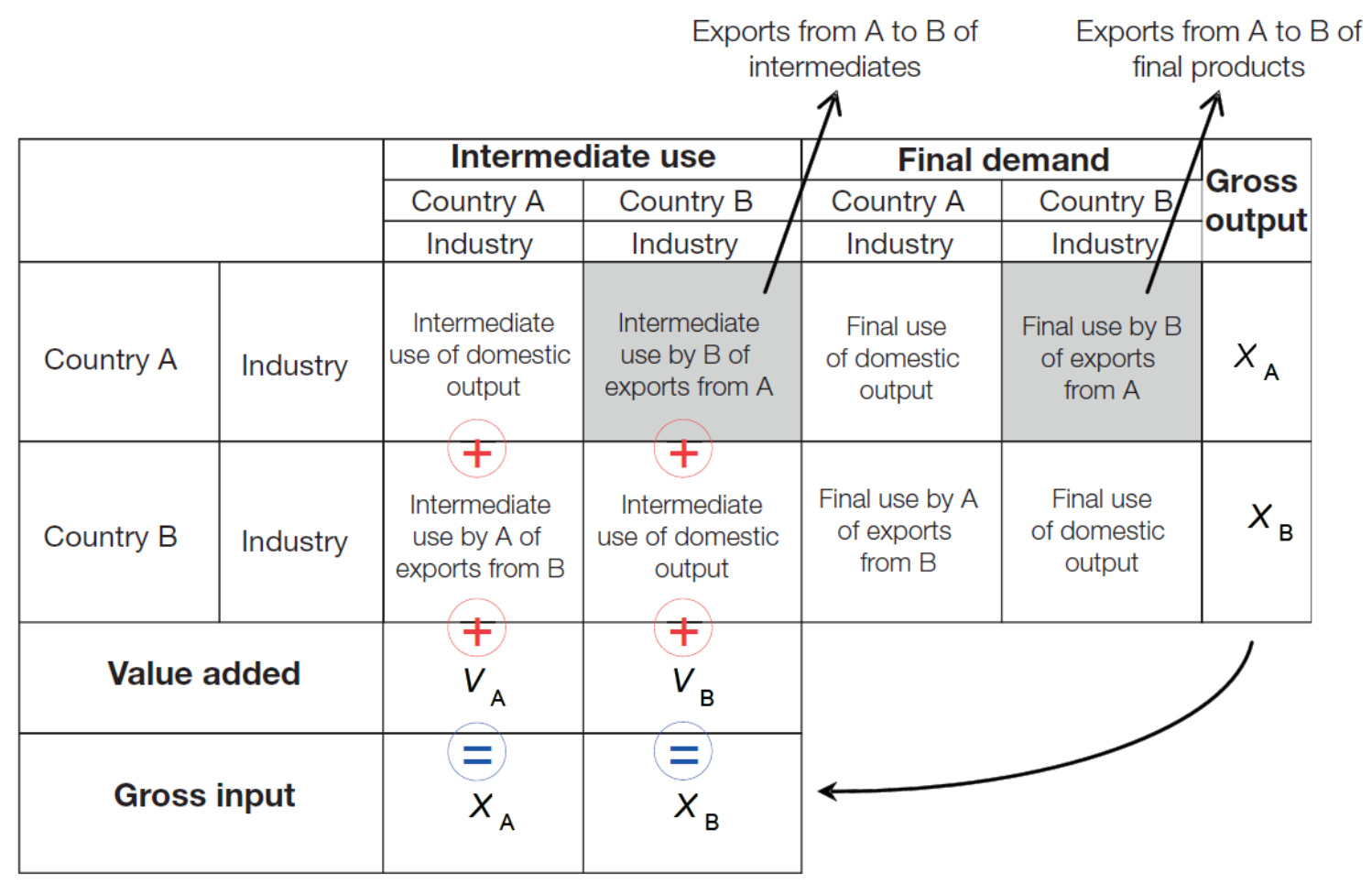

Source: UNCTAD (2013)

When they are stacked as shown in Figure 1, they make up a global input-output table. Note the dimensions of each matrix. In Figure 2, the corresponding matrix T has 12 rows and 12 columns $(3$ countries $\times 4$ sectors $=12)$. The FD matrix has 12 rows (one for each country- 
sector) and 6 columns (two types of final demand for each country). ${ }^{7}$ The VA matrix has 3 rows (one for each country) and 12 columns (one for each country-sector). Overall, the columns of Figure 1 represent all the inputs into the production of each country-sector (values in T and VA matrices). The values in the rows in T and FD matrices tell us where the output of each country-sector is used (i.e. as intermediate inputs to satisfy final demand).

It is important not to confuse the VA matrix (the raw data provided by Eora) with DVA, which is calculated using the elements of the T and FD matrices. The VA matrix gives value added in the accounting sense. This normally includes six items: (1) compensation of employees; (2) taxes on production; (3) subsidies on production; (4) net operating surplus; (5) net mixed income, and (6) consumption of fixed capital. In the examples presented in Figures 1 and 2, these six components are all aggregated in a single category labelled "value added."

\section{A. Calculating Gross Output and Exports}

In this subsection, we demonstrate how to recover some basic trade measures - notably, gross output and gross exports - from the input-output table. Gross output can be calculated in two ways. First, for each of the 12 country-sector rows of the table in Figure 2, we can sum across all the columns of $T$ and $F D$, and the sum will give us the total output of a given sector in each country. For example, summing across the 15 columns of row 5, we get the total output of country 2-sector $1(=7,864$, in Figure 2$)$. Second, for each of the 12 countrysector columns of the table in Figure 2, we can sum across all the rows of the $T$ and $V A$ matrices. For example, summing across the 15 rows of column 5, we get the total input of country 2-sector $1(=7,864$, in Figure 2$)$.

To calculate gross exports, we sum across columns. For example, for gross exports from country 2 -sector 1 to the rest of the world, add up the cells in row five. However, we must exclude the middle 4 cells of the $T$ matrix which correspond to goods from country 2 -sector 1 used in country 2's own onward production, and exclude the middle cell of the FD matrix, which represents the goods from country 2-sector 1 that were consumed in country 2 as final demand. In Figure 2, gross exports from country 2-sector 1 are 5,300. This can, of course, be decomposed into exports to companies abroad (that buy intermediate goods) by summing only the $T$ matrix and excluding country 2 , and exports to foreign final consumers by summing only the $F D$ matrix and excluding country 2.

\footnotetext{
${ }^{7}$ In this example, final demand comprises only household consumption. In the full Eora data, there are 6 components of final demand: (1) household final consumption; (2) non-profit institutions serving households; (3) Government final consumption; (4) gross fixed capital formation; (5) changes in inventories, and (6) acquisitions less disposals of valuables.
} 
Figure 2. Example of Eora MRIO Input-Output Table

\begin{tabular}{|c|c|c|c|c|c|c|c|c|c|c|c|c|c|c|c|c|c|c|}
\hline \multirow[t]{3}{*}{ Year: 2000} & \multirow[b]{3}{*}{$T$ matrix } & \multirow{2}{*}{\multicolumn{4}{|c|}{ Country 1}} & \multirow{2}{*}{\multicolumn{4}{|c|}{ Country 2}} & \multicolumn{9}{|c|}{ Final Demand (FD) Matrix } \\
\hline & & & & & & & & & & \multicolumn{4}{|c|}{ Country 3} & \multirow{2}{*}{$\begin{array}{l}\text { Country } 1 \\
\text { Households }\end{array}$} & \multirow{2}{*}{$\begin{array}{l}\text { Country } 2 \\
\text { Households }\end{array}$} & \multirow{2}{*}{$\begin{array}{l}\text { Country } 3 \\
\text { Households }\end{array}$} & \multirow[b]{2}{*}{ Gross Output } & \multirow[b]{2}{*}{ Gross Exports } \\
\hline & & Sector 1 & Sector 2 & Sector 3 & Sector 4 & Sector 1 & Sector 2 & Sector 3 & Sector 4 & Sector 1 & Sector 2 & Sector 3 & Sector 4 & & & & & \\
\hline Country 1 & Sector 1 & 346 & 156 & 95 & 594 & 819 & 154 & 832 & 397 & 409 & 562 & 241 & 554 & 394 & 902 & 446 & 6,901 & 5,316 \\
\hline Country 1 & Sector 2 & 354 & 443 & 7 & 908 & 42 & 92 & 561 & 839 & 470 & 770 & 83 & 368 & 514 & 694 & 512 & 6,657 & 4,431 \\
\hline Country 1 & Sector 3 & 291 & 795 & 243 & 825 & 753 & 2 & 340 & 232 & 251 & 605 & 526 & 610 & 384 & 753 & 909 & 7,518 & 4,980 \\
\hline Country 1 & Sector 4 & 637 & 259 & 289 & 813 & 500 & 716 & 947 & 645 & 856 & 221 & 898 & 41 & 91 & 653 & 301 & 7,868 & 5,778 \\
\hline Country 2 & Sector 1 & 547 & 466 & 910 & 276 & 518 & 149 & 779 & 553 & 197 & 285 & 305 & 828 & 630 & 565 & 857 & 7,864 & 5,300 \\
\hline Country 2 & Sector 2 & 752 & 936 & 822 & 638 & 611 & 496 & 98 & 924 & 608 & 689 & 872 & 972 & 847 & 209 & 37 & 9,511 & 7,173 \\
\hline Country 2 & Sector 3 & 295 & 444 & 7 & 828 & 929 & 535 & 367 & 257 & 890 & 429 & 641 & 26 & 165 & 419 & 886 & 7,117 & 4,610 \\
\hline Country 2 & Sector 4 & 113 & 518 & 791 & 459 & 79 & 748 & 254 & 218 & 586 & 673 & 424 & 157 & 800 & 355 & 501 & 6,677 & 5,022 \\
\hline Country 3 & Sector 1 & 46 & 457 & 552 & 572 & 632 & 680 & 730 & 607 & 796 & 186 & 15 & 958 & 338 & 320 & 194 & 7,082 & 4,934 \\
\hline Country 3 & Sector 2 & 962 & 96 & 544 & 96 & 675 & 113 & 711 & 337 & 787 & 571 & 241 & 211 & 479 & 14 & 608 & 6,445 & 4,027 \\
\hline Country 3 & Sector 3 & 531 & 190 & 686 & 191 & 374 & 615 & 788 & 738 & 351 & 32 & 565 & 622 & 269 & 814 & 559 & 7,326 & 5,197 \\
\hline \multirow[t]{3}{*}{ Country 3} & Sector 4 & 857 & 776 & 897 & 18 & 915 & 482 & 308 & 458 & 253 & 145 & 982 & 270 & 700 & 822 & 729 & 8,612 & 6,233 \\
\hline & & & & & & & & & & & & & & & & & 89,578 & \\
\hline & VA matrix & & & & & & & & & & & & & & & & & \\
\hline Country 1 & Value Added & 1,172 & 1,120 & 1,676 & 1,648 & - & - & - & - & - & - & - & - & & & & & \\
\hline Country 2 & Value Added & - & - & - & - & 1,019 & 4,730 & 401 & 471 & - & - & - & - & & & & & \\
\hline \multirow[t]{2}{*}{ Country 3} & Value Added & - & - & - & - & - & - & - & - & 626 & 1,278 & 1,532 & 2,995 & & & & & \\
\hline & Total input & 6,901 & 6,657 & 7,518 & 7,868 & 7,864 & 9,511 & 7,117 & 6,677 & 7,082 & 6,445 & 7,326 & 8,612 & 89,578 & & & & \\
\hline
\end{tabular}

Source: Eora MRIO database (http://worldmrio.com/simplified/). 


\section{The MatriX Algebra OF InPUT-OUTPUT TABleS}

\section{A. Basics}

Koopman et al. (2014) provide a detailed exposition of the key concepts needed when calculating trade in value-added terms, both in a simple two-country, one-sector case and in a general case of $G$ countries and $N$ sectors. We encourage the reader to refer to their comprehensive and useful text. Our focus here is on a simple, but realistic, case of a world with 3 countries and 4 sectors each, as in the Figure 1. The equations presented here should make it easier to understand and use the accompanying computer code for use with the full Eora dataset. $^{8}$

Let $\boldsymbol{X}$ be the gross output matrix. Gross output must be used as either intermediate goods or final goods. $\boldsymbol{A}$ is the matrix of input-output coefficients, describing the units of intermediate goods needed to produce one unit of gross output, and therefore $\boldsymbol{A} \boldsymbol{X}$ is the matrix of goods for intermediate use (the $\boldsymbol{T}$ matrix in Eora.) Finally, $\boldsymbol{Y}$ is the matrix of goods used for final demand (the $\boldsymbol{F D}$ matrix in Eora). This basic relationship between gross output, intermediate goods, and final demand goods is expressed below:

$$
\boldsymbol{X}=\boldsymbol{A X}+\boldsymbol{Y}
$$

We can rearrange equation (1) such that $\boldsymbol{X}=\boldsymbol{B} \boldsymbol{Y}$, where

$$
\boldsymbol{B}=(\boldsymbol{I}-\boldsymbol{A})^{-1}
$$

is the Leontief inverse matrix, elements of which express the total output required both directly and indirectly to produce a unit of goods for final demand. To calculate the Leontief inverse matrix, we need to recover $\boldsymbol{A}$, the matrix of input-output coefficients.

\footnotetext{
${ }^{8}$ There are two files of accompanying Matlab code. The first Matlab code was written using with the toy example (3 countries, 4 sectors each; see Eora_example_calc_userguide.m), and may be helpful for step-by-step calcualtions using block matrices, via loops, but this approach comes at the cost of efficiency. The second Matlab code (see code_eora_c_final.m) assumes the use of full Eora data and and, when used with full Eora data it will run faster. Essentially most of the same concepts are coded in two different ways, to assist the reader.
} 
Let's get closer to the actual data. We can express our $G$-country $N$-sector production and trade system in equation (1) as an inter-country input-output model-recall $G=3$ and $N=4$ in our example - as follows:

$$
\left[\begin{array}{l}
\sum_{r}^{G=3} \boldsymbol{X}_{1 r} \\
\sum_{r}^{G=3} \boldsymbol{X}_{2 r} \\
\sum_{r}^{G=3} \boldsymbol{X}_{3 r}
\end{array}\right]_{12 \times 1}=\left[\begin{array}{lll}
\boldsymbol{A}_{11} & \boldsymbol{A}_{12} & \boldsymbol{A}_{13} \\
\boldsymbol{A}_{21} & \boldsymbol{A}_{22} & \boldsymbol{A}_{23} \\
\boldsymbol{A}_{31} & \boldsymbol{A}_{32} & \boldsymbol{A}_{33}
\end{array}\right]_{12 \times 12}\left[\begin{array}{l}
\sum_{r}^{G=3} \boldsymbol{Y}_{1 r} \\
\sum_{r=3}^{G=3} \boldsymbol{Y}_{2 r} \\
\sum_{r} \boldsymbol{Y}_{3 r}
\end{array}\right]_{12 \times 1}
$$

where $\boldsymbol{X}_{s r}$ is a $N \times 1(4 \times 1)$ vector that gives the gross output produced in country $s$ and absorbed in country $r ; \boldsymbol{Y}_{S r}$ is a $N \times 1(4 \times 1)$ vector that gives final goods produced in country $s$ and absorbed in country $r$, and $\boldsymbol{A}_{s r}$ is a $N \times N(4 \times 4)$ matrix of input-output coefficients. The $\boldsymbol{B}$ matrix can also be written analogously to $\boldsymbol{A}$, where $\boldsymbol{B}_{s r}$ is a $N \times N(4 \times 4)$ block matrix, also called the total requirements matrix.

From Eora, we get the $\boldsymbol{T}_{\text {eora }}$ data matrix, which gives us information about the intermediate goods use. $\boldsymbol{T}^{\text {eora }}$ is a $G N \times G N(12 \times 12)$ matrix:

$$
\boldsymbol{T}^{\text {eora }}=\left[\begin{array}{lll}
\boldsymbol{T}_{11} & \boldsymbol{T}_{12} & \boldsymbol{T}_{13} \\
\boldsymbol{T}_{21} & \boldsymbol{T}_{22} & \boldsymbol{T}_{23} \\
\boldsymbol{T}_{31} & \boldsymbol{T}_{32} & \boldsymbol{T}_{33}
\end{array}\right]_{12 \times 12}
$$

Expressing $\boldsymbol{T}$ as follows:

$$
\boldsymbol{T}=\left[\begin{array}{l}
\sum_{r}^{G=3} \boldsymbol{T}_{1 r} \\
\sum_{r=3}^{G=3} \boldsymbol{T}_{2 r} \\
\sum_{r} \boldsymbol{T}_{3 r}
\end{array}\right]_{12 \times 1}
$$

you can verify, using the accompanying code, that $\boldsymbol{A X}=\boldsymbol{T}$.

Now, we can use the $\boldsymbol{T}^{\text {eora }}$ data matrix to recover the $\boldsymbol{A}$ matrix of input-output coefficients. Note that $\boldsymbol{A} \boldsymbol{X}=\boldsymbol{T}$ implies that element-wise multiplication of each of the $G \times N(3 \times 4)$ rows of $\boldsymbol{A}$ (pertaining to each country and each sector) with the transpose of the $\boldsymbol{X}$ vector, will produce exactly each corresponding row of matrix $\boldsymbol{T}^{\text {eora }}$. Using this logic, we can calculate 
each element $\boldsymbol{A}_{s r}$ of matrix $\boldsymbol{A}$, by dividing the corresponding element of matrix $\boldsymbol{T}^{\text {eora }}$ with the corresponding element of the $\boldsymbol{X}$ vector of gross output:

$$
\boldsymbol{A}_{s r}=\boldsymbol{T}_{s r}^{e o r a} \quad \boldsymbol{X}_{s}
$$

where " $\oslash$ " denotes element-wise division. The same expression can also be written in matrix form:

$$
\boldsymbol{A}=\boldsymbol{T}^{\text {eora }} \oslash\left[\begin{array}{c}
\boldsymbol{X}^{\prime} \\
\vdots \\
\boldsymbol{X}^{\prime}
\end{array}\right]_{12 \times 1}
$$

Once matrix $\boldsymbol{A}$ is recovered, it is easy to calculate $\boldsymbol{B}$, using the Leontief inverse in equation (2).

To calculate FVA and DVA, we also need to recover the matrix of value-added shares, $\widehat{\boldsymbol{V}}$, also called the value-added coefficients matrix. $\widehat{V}$ can be obtained by summing across rows of the $A$ matrix, putting these elements on the diagonal of a square matrix and subtracting it from an identity matrix of size $G N \times G N(12 \times 12)$, as follows:

$$
\begin{gathered}
\widehat{\boldsymbol{V}}=I_{12 \times 12}-\operatorname{diag}\left(\sum_{s}^{G N=12} \boldsymbol{A}_{s 1} \cdots \sum_{s}^{G N=12} \boldsymbol{A}_{s 12}\right) \\
\widehat{\boldsymbol{V}}=\left[\begin{array}{cccc}
\hat{v}_{1} & 0 & \cdots & 0 \\
0 & \hat{v}_{2} & \cdots & 0 \\
\vdots & \vdots & \ddots & \vdots \\
0 & 0 & \cdots & \hat{v}_{G N=12}
\end{array}\right]
\end{gathered}
$$

Finally, multiplying the $\widehat{\boldsymbol{V}}$ matrix with $\boldsymbol{B}$ and the matrix of gross exports, we get the matrix $\boldsymbol{T}_{v}$, borrowing notation from UNCTAD (2013). ${ }^{9}$ For the general $G$-country $N$-sector case, this is given below:

$$
\boldsymbol{T}_{v}=\left[\begin{array}{cccc}
\hat{v}_{1} & 0 & \cdots & 0 \\
0 & \hat{v}_{2} & \cdots & 0 \\
\vdots & \vdots & \ddots & \vdots \\
0 & 0 & \cdots & \hat{v}_{G N}
\end{array}\right]\left[\begin{array}{cccc}
\boldsymbol{B}_{11} & \boldsymbol{B}_{12} & \cdots & \boldsymbol{B}_{1 G} \\
\boldsymbol{B}_{21} & \boldsymbol{B}_{22} & \cdots & \boldsymbol{B}_{2 G} \\
\vdots & \vdots & \ddots & \vdots \\
\boldsymbol{B}_{G 1} & B_{G 2} & \cdots & \boldsymbol{B}_{G G}
\end{array}\right]\left[\begin{array}{cccc}
e_{1} & 0 & \cdots & 0 \\
0 & e_{2} & \cdots & 0 \\
\vdots & \vdots & \ddots & \vdots \\
0 & 0 & \cdots & e_{G N}
\end{array}\right]
$$

Note that in the matrix of gross exports in equation (4), each element on the diagonal gives the gross exports for the corresponding country-sector.

\footnotetext{
${ }^{9}$ Note that notation $T v$ does not imply matrix multiplication.
} 


\section{B. Calculating domestic and foreign value added}

Armed with the $\boldsymbol{T}_{v}$ matrix in block matrix notation:

$$
\boldsymbol{T}_{v}=\left[\begin{array}{cccc}
\boldsymbol{T}_{v_{11}} & \boldsymbol{T}_{v_{11}} & \cdots & \boldsymbol{T}_{v_{11}} \\
\boldsymbol{T}_{v_{11}} & \boldsymbol{T}_{v_{22}} & \cdots & \boldsymbol{T}_{v_{11}} \\
\vdots & \vdots & \ddots & \vdots \\
\boldsymbol{T}_{v_{11}} & \boldsymbol{T}_{v_{11}} & \cdots & \boldsymbol{T}_{v_{G G}}
\end{array}\right]
$$

we are now ready to calculate domestic value added (DVA), indirect value added (DVX), and foreign value added (FVA), which are highlighted in Figure 3 as different components of the $\boldsymbol{T}_{v}$, matrix. The DVA for each country is given by the diagonal elements of the $\boldsymbol{T}_{v}$ matrix. FVA for each country can be calculated by simply summing up all the blocks in the corresponding column and subtracting the diagonal block matrix. Note that DVA and FVA, by construction, always add up to gross exports (or to unity if expressed as ratios to gross exports). DVX for each country-sector can be calculated by summing up all the blocks in the corresponding row and subtracting the diagonal block matrix. Similarly, we can calculate DVA, DVX, and FVA at the country-sector level, by summing over only over the corresponding rows or columns of the country block matrix. The accompanying MATLAB code calculates FVA, DVA and DVX at both the country and country-sector level.

The value-added shares matrix, $\widehat{\boldsymbol{V}} \boldsymbol{B}$, contains all the necessary information on value-added production by source that is embedded in the input-output table (see discussion in Koopman et al, 2014). For example, if we multiply $\widehat{\boldsymbol{V}} \boldsymbol{B}$ by $\boldsymbol{I}$, where $\boldsymbol{I}$ is the $G N \times G N$ identity matrix, and extract DVA from the diagonal blocks and FVA from all the column blocks less the diagonal, we would obtain the same DVA and FVA shares as above. Also, if we sum up across rows of the $\widehat{\boldsymbol{V}} \boldsymbol{B}$ we will get a horizontal vector of ones, i.e., each column sums up exactly to 1 . 
Figure 3. Value-Added Content of Trade

\begin{tabular}{|c|c|c|c|c|c|c|c|c|}
\hline & & & & & & & & \\
\hline & & Country 1 & Country 2 & Country 3 & $\ldots$ & Country k & $\ldots$ & Country N \\
\hline DVA & Country 1 & $-\mathrm{T}_{\mathrm{v}}{ }^{11}$ & म्य & त्य & & $\mathrm{uk}$ & & $\mathrm{dN}$ \\
\hline & Country 2 & -21 & $\mathrm{~T}_{\mathrm{v}}{ }^{22}$ & $\mathrm{~T}_{v}{ }^{23}$ & $\ldots$ & $\mathrm{T}_{\mathrm{v}}{ }^{2 \mathrm{k}}$ & $\ldots$ & $\mathrm{T}_{\mathrm{v}}{ }^{2 \mathrm{~N}}$ \\
\hline & Country 3 & $F-31$ & $\mathrm{~T}_{\mathrm{v}}{ }^{32}$ & $\mathrm{~T}_{\mathrm{v}}{ }^{33}$ & $\ldots$ & $\mathrm{T}_{\mathrm{v}}^{3 \mathrm{k}}$ & $\ldots$ & $\mathrm{T}_{\mathrm{v}}{ }^{3 \mathrm{~N}}$ \\
\hline FVA & $\ldots$ & 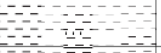 & $\ldots$ & $\ldots$ & $\ldots$ & $\ldots$ & $\ldots$ & $\ldots$ \\
\hline & Country $\mathrm{k}$ & $F=$ & $\mathrm{T}_{\mathrm{v}}{ }^{\mathrm{k} 2}$ & $\mathrm{~T}_{\mathrm{v}}^{\mathrm{k} 3}$ & $\ldots$ & $\mathrm{T}_{\mathrm{v}}^{\mathrm{kk}}$ & $\ldots$ & $\mathrm{T}_{\mathrm{v}}{ }^{\mathrm{kN}}$ \\
\hline & $\ldots$ & & $\ldots$ & $\ldots$ & $\ldots$ & $\ldots$ & $\ldots$ & $\ldots$ \\
\hline & Country N & EN & $\mathrm{T}_{\mathrm{v}}{ }^{\mathrm{N} 2}$ & $\mathrm{~T}_{\mathrm{v}}{ }^{\mathrm{N} 3}$ & $\ldots$ & $\mathrm{T}_{\mathrm{v}}{ }^{\mathrm{Nk}}$ & $\ldots$ & $\mathrm{T}_{\mathrm{v}}^{\mathrm{NN}}$ \\
\hline
\end{tabular}

Source: UNCTAD (2013).

Figure 4. Decomposition of Gross Exports

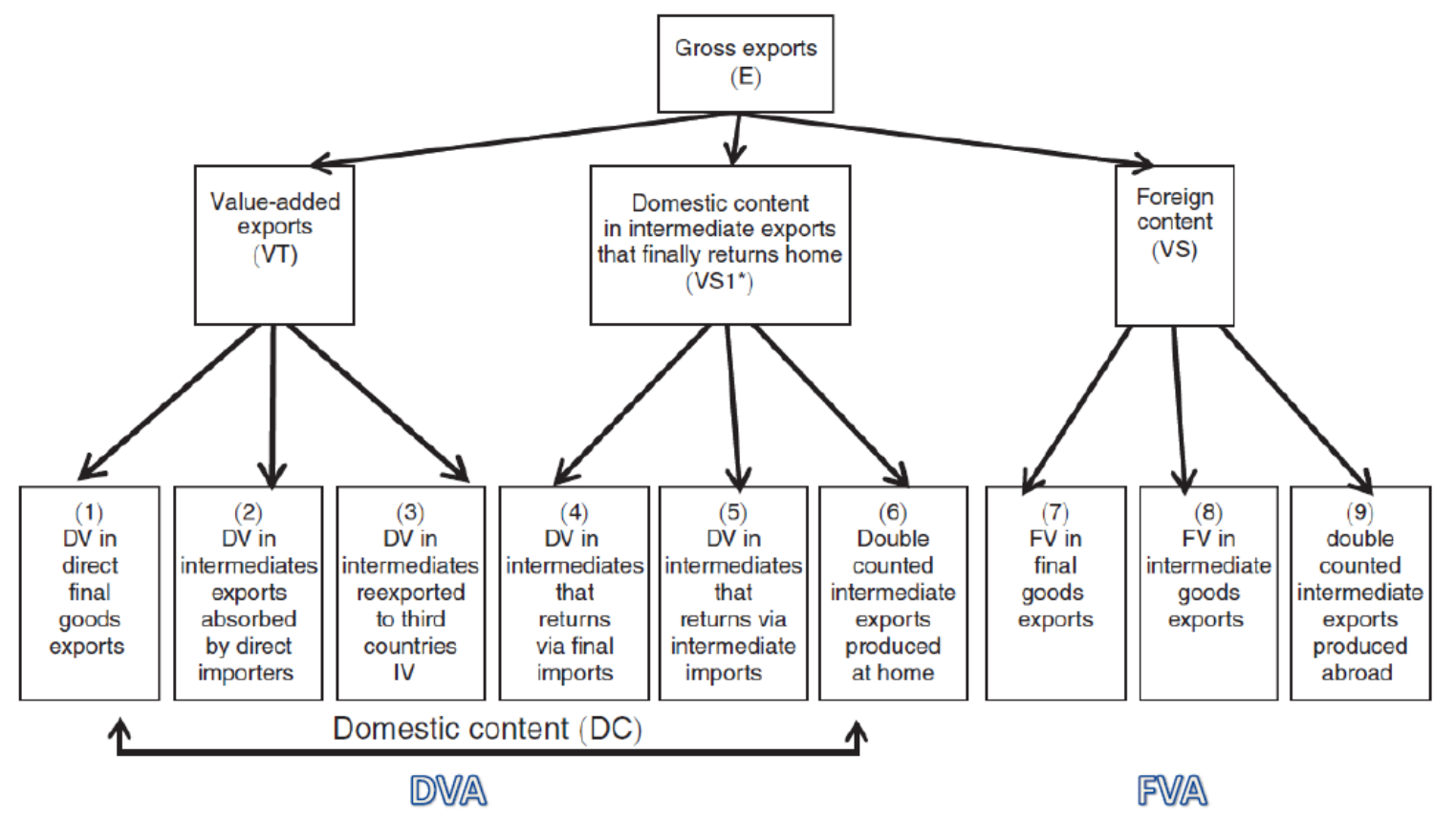

Source: Koopman et al (2014). 


\section{Detailed Decomposition of Gross Exports}

Going beyond the broad categories of DVA and FVA, Koopman et al. (2014) introduce a detailed decomposition of gross exports into 9 components, as in Figure $4 .{ }^{10}$ Specifically, the authors calculate multiple value-added components by source, as well as additional doublecounted terms. ${ }^{11}$ Their framework bridges a gap between official trade statistics (in gross value terms) and national accounts (in value-added terms). As discussed below, it also incorporates all previous measures of vertical specialization and value-added trade in the literature while adjusting for the back-and-forth trade of intermediates across multiple borders. The decomposition is as follows:

$$
\begin{aligned}
& \boldsymbol{u}_{s *}=\left\{\boldsymbol{V}_{s} \sum_{r \neq s}^{G} \boldsymbol{B}_{s s} \boldsymbol{Y}_{s r}+\boldsymbol{V}_{s} \sum_{r \neq s}^{G} \boldsymbol{B}_{s r} \boldsymbol{Y}_{r r}+\boldsymbol{V}_{s} \sum_{r \neq s}^{G} \sum_{t \neq s, r}^{G} \boldsymbol{B}_{s r} \boldsymbol{Y}_{r t}\right\} \\
& +\left\{\boldsymbol{V}_{s} \sum_{r \neq s}^{G} \boldsymbol{B}_{s r} \boldsymbol{Y}_{r s}+\boldsymbol{V}_{s} \sum_{r \neq s}^{G} \boldsymbol{B}_{s r} \boldsymbol{A}_{r s}\left(I-\boldsymbol{A}_{s s}\right)^{-1} \boldsymbol{Y}_{s s}\right\} \\
& +\boldsymbol{V}_{s} \sum_{r \neq s}^{G} \boldsymbol{B}_{s r} \boldsymbol{A}_{r s}\left(I-\boldsymbol{A}_{s s}\right)^{-1} \boldsymbol{E}_{s *} \\
& +\left\{\sum_{t \neq s}^{G} \sum_{r \neq s}^{G} \boldsymbol{V}_{t} \boldsymbol{B}_{t s} \boldsymbol{Y}_{s r}+\sum_{t \neq s}^{G} \sum_{r \neq s}^{G} \boldsymbol{V}_{t} \boldsymbol{B}_{t s} \boldsymbol{A}_{s r}\left(I-\boldsymbol{A}_{r r}\right)^{-1} \boldsymbol{Y}_{r r}\right\} \\
& +\sum_{t \neq s}^{G} \boldsymbol{V}_{t} \boldsymbol{B}_{t s} \boldsymbol{A}_{s r} \sum_{r \neq s}^{G}\left(I-\boldsymbol{A}_{r r}\right)^{-1} \boldsymbol{E}_{r *}
\end{aligned}
$$

where $\boldsymbol{E}_{S *}$ are a country's gross exports to the world.

Using the breakdown from Figure 4, the sum of the first six terms of equation (5) is equal to DVA (also referred to as the domestic content of gross exports), while the sum of terms 7, 8, and 9 give FVA. The sum of the first three terms is also called value-added exports, or VAX (Johnson and Noguera, 2012), which is considered a better measure of domestic value-added than DVA, which also accounts for domestic content in intermediate exports that finally returns home (terms 4, 5 and 6). These latter terms include a double counting item, as well as goods that return to the origin country via imports.

The MATLAB code that accompanies this user guide calculates these 9 terms separately. Term 3 might be of particular interest as it directly calculates the domestic value added of

\footnotetext{
10 This decomposition can be found in equation (36) of Koopman et al (2014).

${ }^{11}$ Borin and Mancini (2015) refine the framework in Koopman et al. (2014), by distinguishing further between the DVA in intermediate exports absorbed by direct importers and that going for final use in a third country in terms 2, 3, and 4 of the decomposition.
} 
intermediates reexported to third countries, and is one measure of the likely length of the GVC. Presumably, if a country exports intermediate inputs that are reexported to third countries it participates in longer value chains — as discussed in IMF (2015b).

Value-added exports - value added produced in one country and absorbed in anothercaptures the income generated by exporting and has formed an increasing share of global income since the early 1990s. Global value-added exports have increased from around 11 percent of world GDP in 1990 to around 20 percent in 2008. Since then, this fraction has remained broadly constant, with exception of a dip around the time of the global financial crisis. Figure 5 plots VAX over time as a share of world output for a selection of countries and regions, derived using the global Eora MRIO tables.

Figure 5. World Value-Added Exports by Country and Region

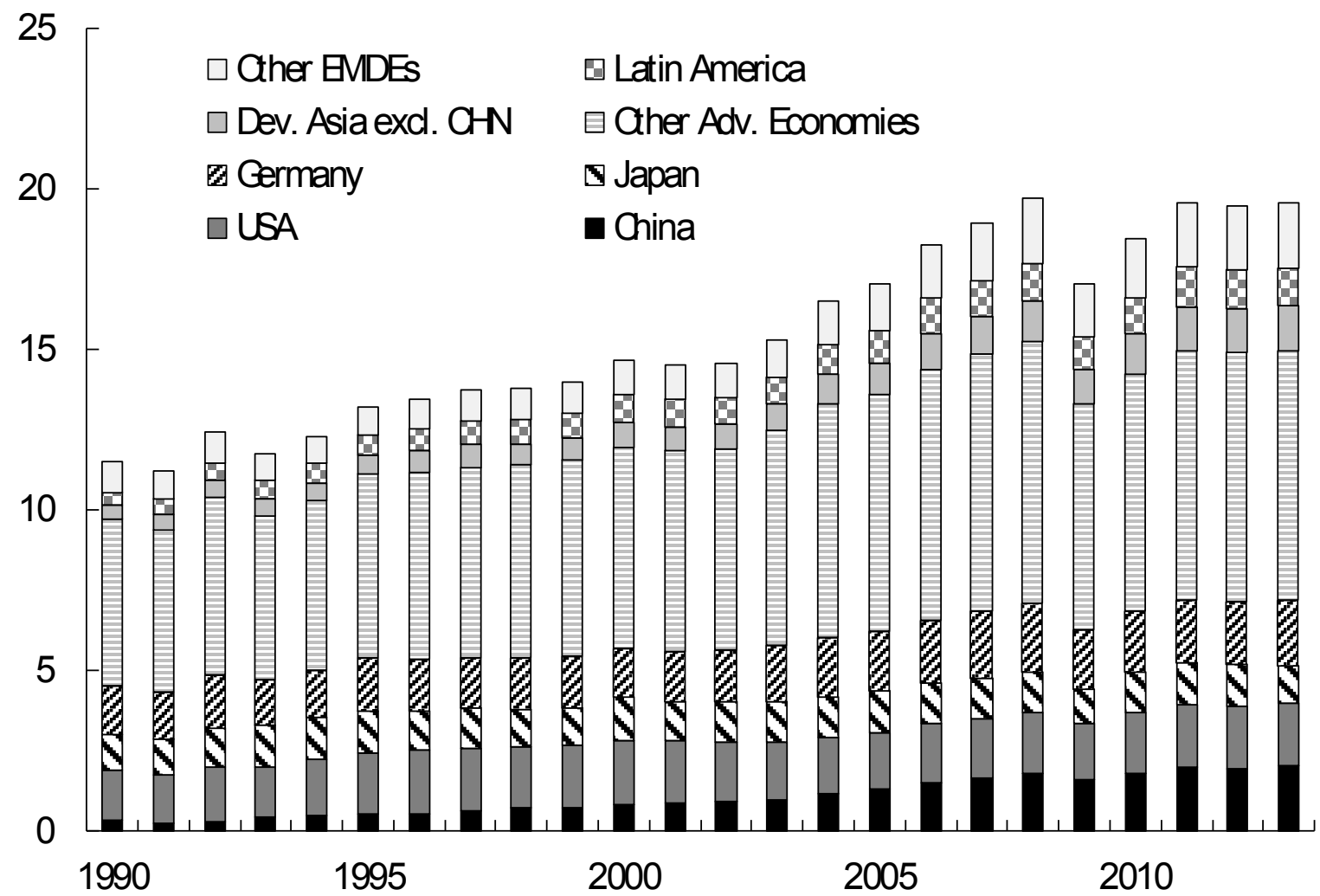

Sources: Eora MRIO Database and IMF staff calculations.

Most countries and regions can be seen to have increased contributions to world output though exporting. Contributions by emerging market countries have been particularly significant: value-added exports of China increased from 0.3 percent of world output in 1995 to 1.8 percent by 2008 and have increased to 2.0 percent in 2013 (representing a 5-fold increase). Following closely behind are countries in developing Asia (excl. China), which increased from 0.4 percent to 1.4 percent over a similar period. 
We can also derive a direct relationship between DVX and the 9-term gross exports decomposition. ${ }^{12}$ DVX can be calculated as:

$$
D V X_{s}=\boldsymbol{V}_{s} \sum_{r \neq s}^{G} \boldsymbol{B}_{s r} \boldsymbol{E}_{r *}
$$

which can be shown to equal the sum of terms $3,4,5$, and 6 , in equation (5) and an additional term, $D V X_{s}^{*}$, which is defined as:

$$
D V X_{s}^{*}=\boldsymbol{V}_{s} \sum_{r \neq s}^{G} \sum_{t \neq s, r}^{G} \boldsymbol{B}_{s r} \boldsymbol{A}_{r t} \boldsymbol{X}_{t}
$$

This additional term gives the domestic content in exported goods that is used as imported inputs to produce other countries' intermediate goods exports.

\section{Measures of Global Value Chain Participation}

As noted in Haltmeier (2015), Hummels et al. (2001) and Chen et. al. (2005), previous measures for GVCs - for example, imported input shares of gross output, total inputs, or exports - do not accurately characterize the extent of a country's involvement in such chains. This is because such measures are unable to assess the extent to which imported intermediates are used in a country's exports as opposed to domestic production. Hummels et al. (2001) introduced the concept of "vertical specialization," which requires three characteristics, the third of which distinguishes a value chain from simple outsourcing:

1. goods are produced in stages;

2. two or more countries provide value added in the production sequence;

3. at least one country uses imported inputs in its stage of the production process and exports some of the resulting product to either a third country or back to the country of origin.

Furthermore, Hummels et al. (2001) developed two measures of vertical specialization for an individual country, one from the import perspective and the other from the export perspective:

- VS (from import perspective): this is the imported intermediate input content of exports, which is measured for each country and each product as the amount of imported intermediate input multiplied by the ratio of exports to gross output for that product. The total for a country is calculated by summing across products. This statistic approximates the actual number of intermediates used for export as it

\footnotetext{
${ }^{12}$ See equation (42) of Koopman et al. (2014).
} 
assumes that the ratio of intermediates to output is the same for output that is sold domestically and output that is exported.

- VS1 (from export perspective): counts the portion of exports that are used by another country in the production of its export goods. It is calculated for each country as the sum over all products and destinations of its exports of intermediates multiplied by the ratio of exports to gross output for that industry in the destination country. Again, this is an approximation that assumes that the usage of each intermediate input is proportionately the same for exports as for products sold domestically.

Both measures will seem familiar: VS is simply the FVA already encountered, while VS1 is DVX. If FVA and DVX are expressed as percent of exports, then the formula for GVC participation is as follows:

$$
G V C_{\text {Participation }}=\frac{F V A+D V X}{\text { Gross Exports }}
$$

The larger the ratio, the greater the intensity of involvement of a particular country in GVCs. FVA (or VS) is also referred to as a measure of "backward participation", given that it measures imported intermediate inputs that used to generate output for export. DVX is a measure of "forward participation", i.e. it measures exports of intermediate goods that are used as inputs for the production of exports of other countries. ${ }^{13}$

Koopman et al. (2014) also define a position index that characterizes the relative upstreamness of a country in particular industry. They propose measuring upstreamness as the log ratio of a country's supply of intermediates used in other countries' exports to the use of imported intermediates in its own production:

$$
\ln \left(1+\frac{D V X}{\text { Gross Exports }}\right)-\ln \left(1+\frac{F V A}{\text { Gross Exports }}\right)
$$

Countries with a larger position index are relatively more upstream, i.e., they contribute more value added to other countries exports than other countries contribute to theirs. Of course, two countries can have identical values of the GVC position index in a sector while having very different degrees of participation in GVCs. Therefore, the position index should

\footnotetext{
${ }^{13}$ It is important to note that it was recent work by Johnson and Noguera (2012) and Koopman et al. (2014) that generalized Hummels et al. (2001) vertical specialization measures to complex production chains. Koopman et al. (2014) demonstrate that the VS and VS1 measures do not accurately decompose exports into their foreign and domestic value-added components when the production chain spans several countries, i.e., when one country imports intermediate inputs, adds value, and then exports semi-finished goods to another country that produces the final goods. In these cases, it is not accurate to assume that imports from a source country embody only domestic value added from that country, as they may also include value added from third countries. These more complicated production chains may include the increasingly important phenomenon of round-tripping, in which intermediate goods may cross the same borders several times, with some of a country's intermediate goods imports embodying some of its own value added.
} 
be used in conjunction with the participation index, which summarizes the importance of the global supply chain for that country.

Figure 6 shows the relationship between GVC participation and position for advanced economies (AEs), emerging market and developing economies (EMDEs) excluding China, and China. For the regional scatters, the country-specific GVC measures are weighted by the share of each country's gross exports in total regional gross exports. Each dot represents the average participation and position in a particular year (all years 1990-2013 are plotted). What we can see is that both AEs and EMDEs excluding China have on average continued to increase their participation in GVCs over time - AEs noticeably more so. However, while EMDEs excluding China have begun to move more upstream, AEs have begun to move more downstream. At the same time, China participation in GVCs also appears to plateau recently, while China shifts back upstream.

\section{Figure 6. The Shifting Pattern of GVC Participation and Position}

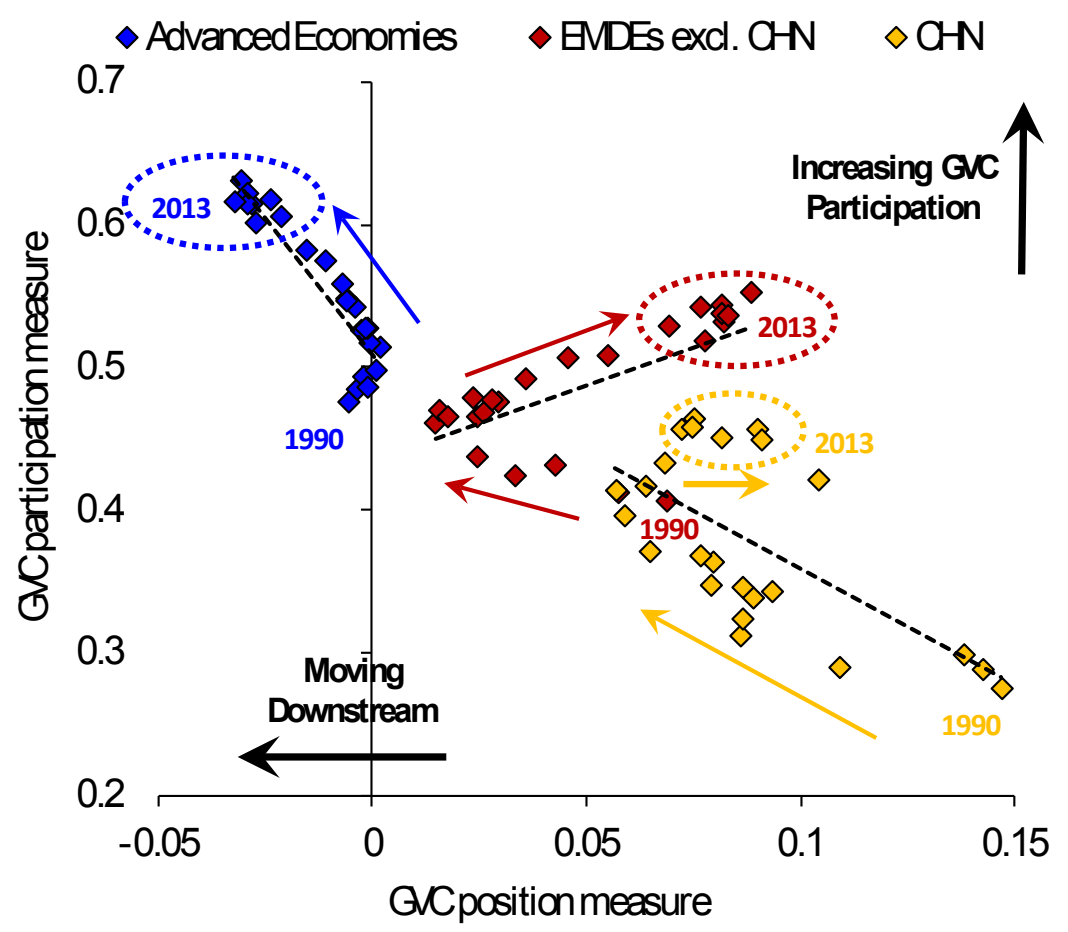

Sources: Eora MRIO Database and IMF staff calculations.

\section{EORA VS. OTHER INPUT-OUTPUT TABLES}

Before concluding, we wanted to compare Eora data to those from other input-output tables. As mentioned before, Eora is only one of several available input-output tables. Of course, the benefit of Eora is that it has greater country and time coverage than other sources. However, one might worry this comes at a cost of data reliability. For this reason, we have compared 
FVA calculated from Eora to the FVA given by the OECD-WTO Trade in Value Added (TiVA) initiative, which should be the most reliable government-approved source. This is done separately for years 1995, 2000, 2005, 2008, 2009, 2010, and 2011, presented in Figures 7-13.

As a check for Eora, FVA calculated from both Eora and the FVA provided by OECD-WTO TiVA, should be broadly similar in each year for most countries. Hence a scatter plot of one source against the other value should, in theory, lie close to the 45-degree line. However, this theoretical ideal is unattainable given data limitations and the different approaches and assumptions used when the two sets of input-output tables are generated. It can be considered a success if FVA from the two sources are highly correlated.

Overall, the scatterplots presented reassure us that Eora and OECD-WTO TiVA statistics are generally consistent with one another. Given this, we can feel somewhat more comfortable using Eora for countries for which the OECD-WTO data are not available. However, the researcher should be aware of possible problems, given the method by which the input-output tables have been constructed for countries where no official supply-use tables are available. Some important country examples, such as China, Hong Kong etc. depending on the year, have Eora data points that are not aligned with those of the OECD-WTO.

\section{Conclusion}

The global Eora MRIO tables offer a rich unified cross-country dataset which can be used to calculate trade in value-added statistics for almost all countries starting in 1990. This country dataset far exceeds the coverage of countries available from other sources. We have provided an overview of the basic algebra, together with accompanying MATLAB codes, to assist in using this large dataset to calculate trade in value-added for policy analysis. A brief look at the nature of forward and backward production linkages, as well as countries' participation and position in global value chains is also provided. 
Figure 7: Comparing FVA from Eora and OECD-WTO Trade in Value-Added, 1995

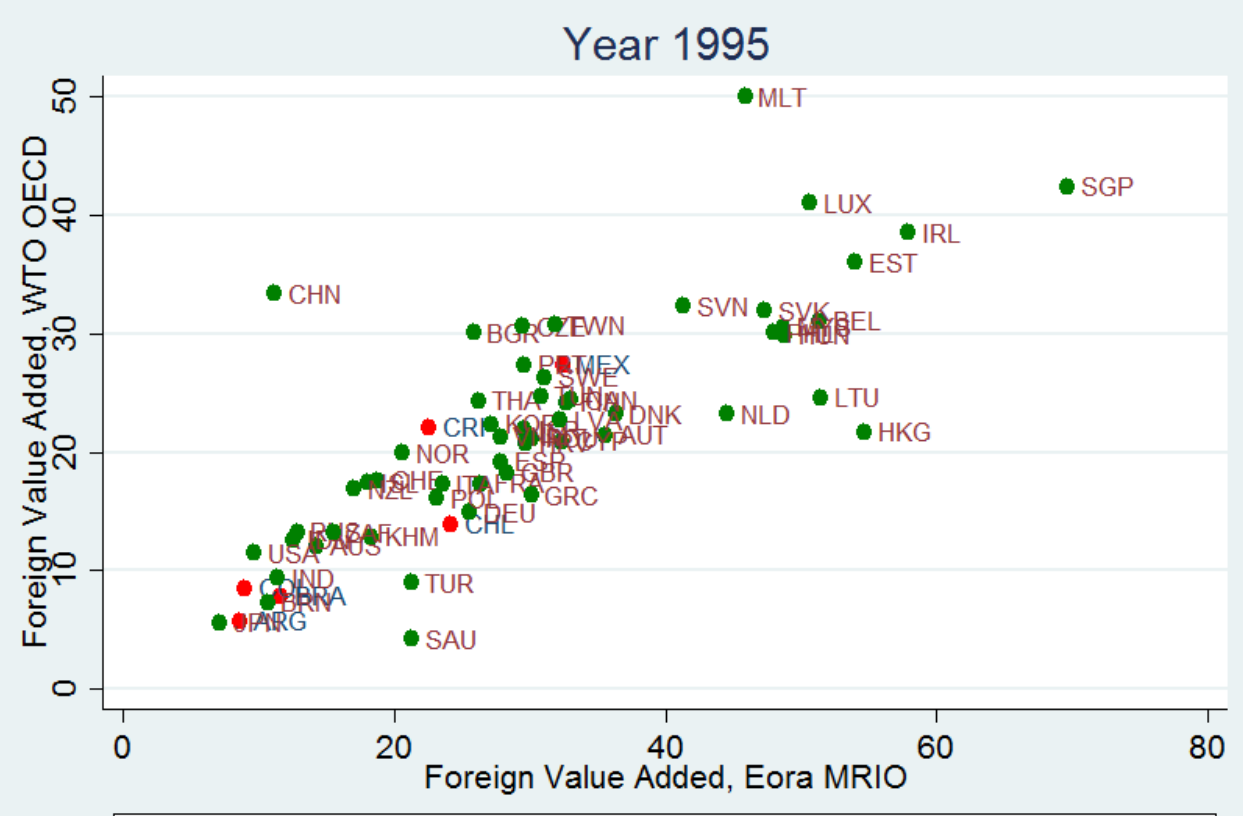

- Foreign Value Added, WTO OECD • Foreign Value Added, WTO OECD

Figure 8: Comparing FVA from Eora and OECD-WTO Trade in Value-Added, 2000

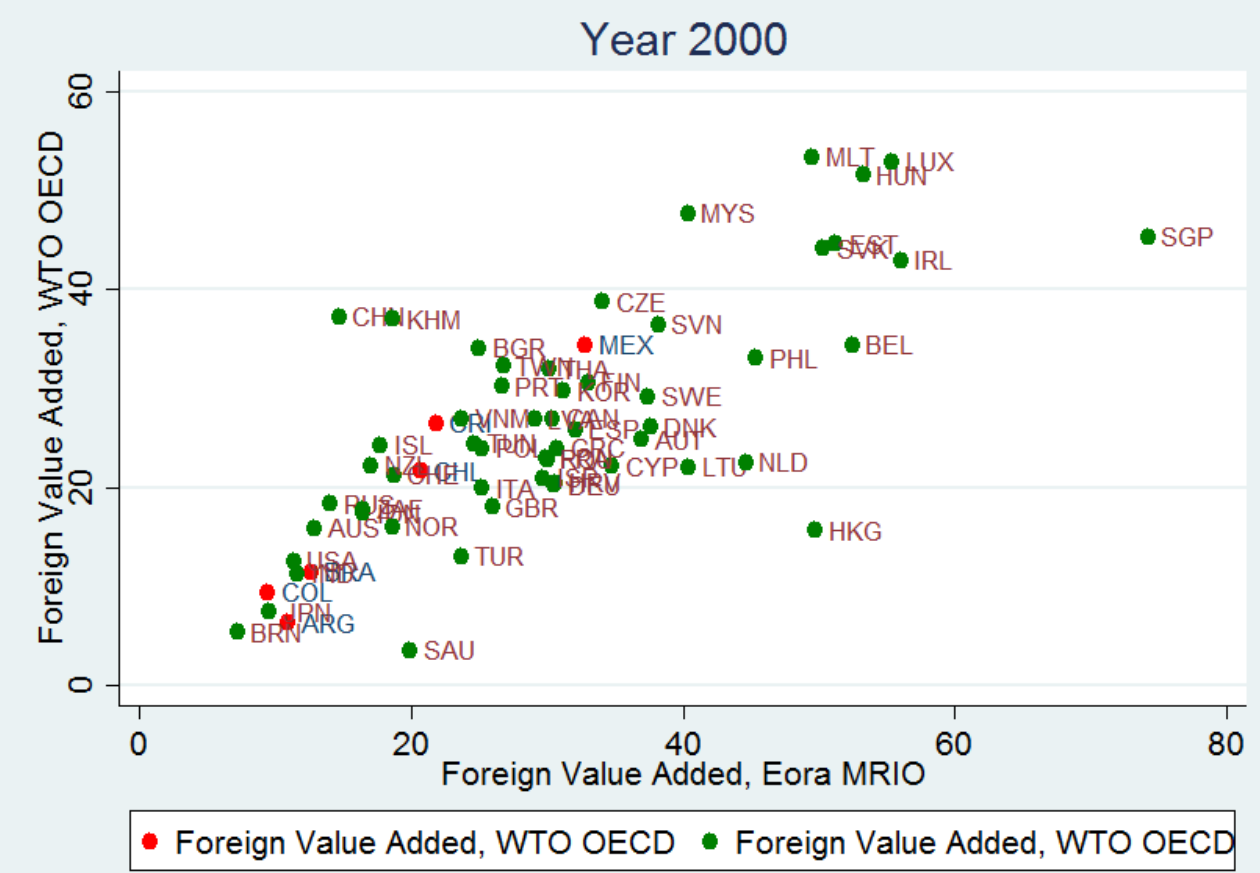

C)International Monetary Fund. Not for Redistribution 
Figure 9: Comparing FVA from Eora and OECD-WTO Trade in Value-Added, 2005

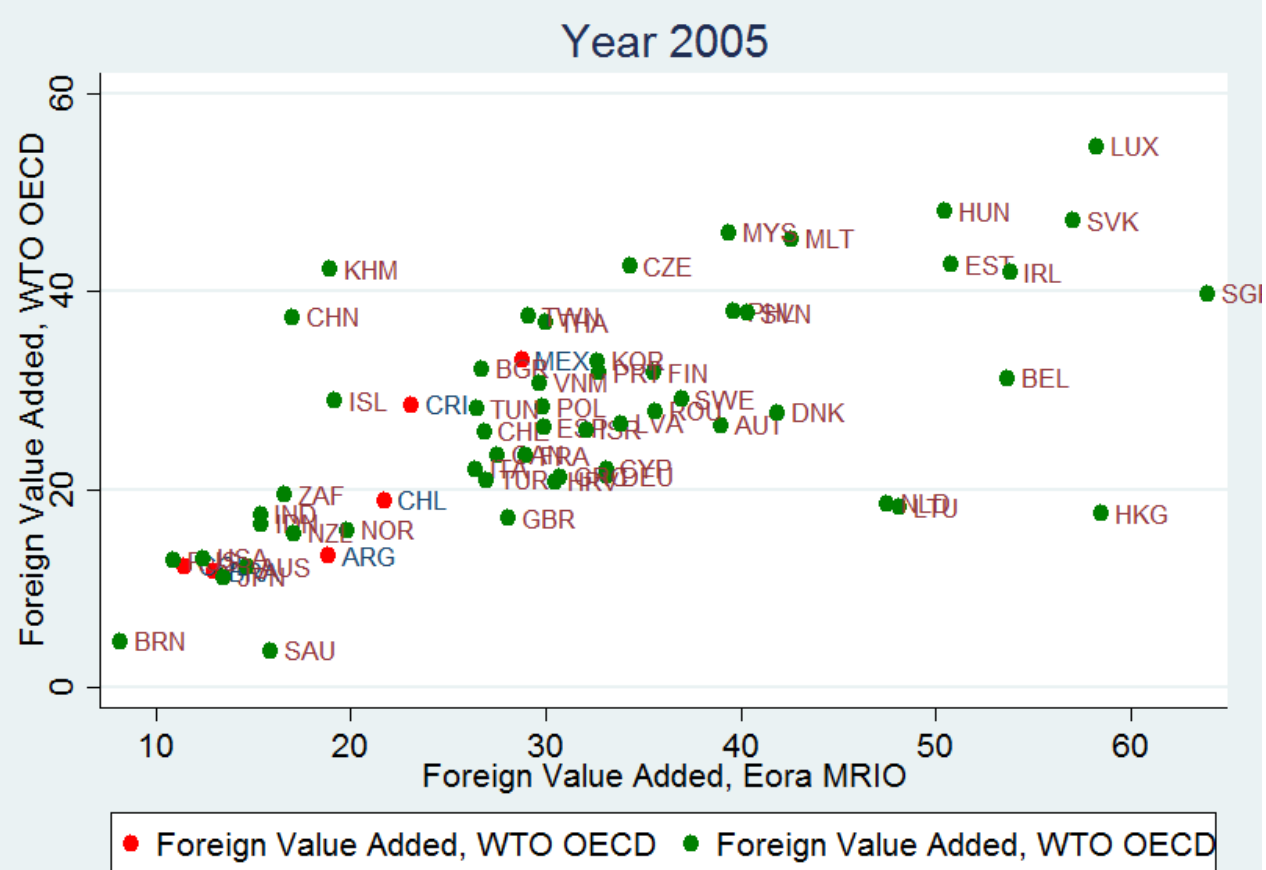

Figure 10: Comparing FVA from Eora and OECD-WTO Trade in Value-Added, 2008

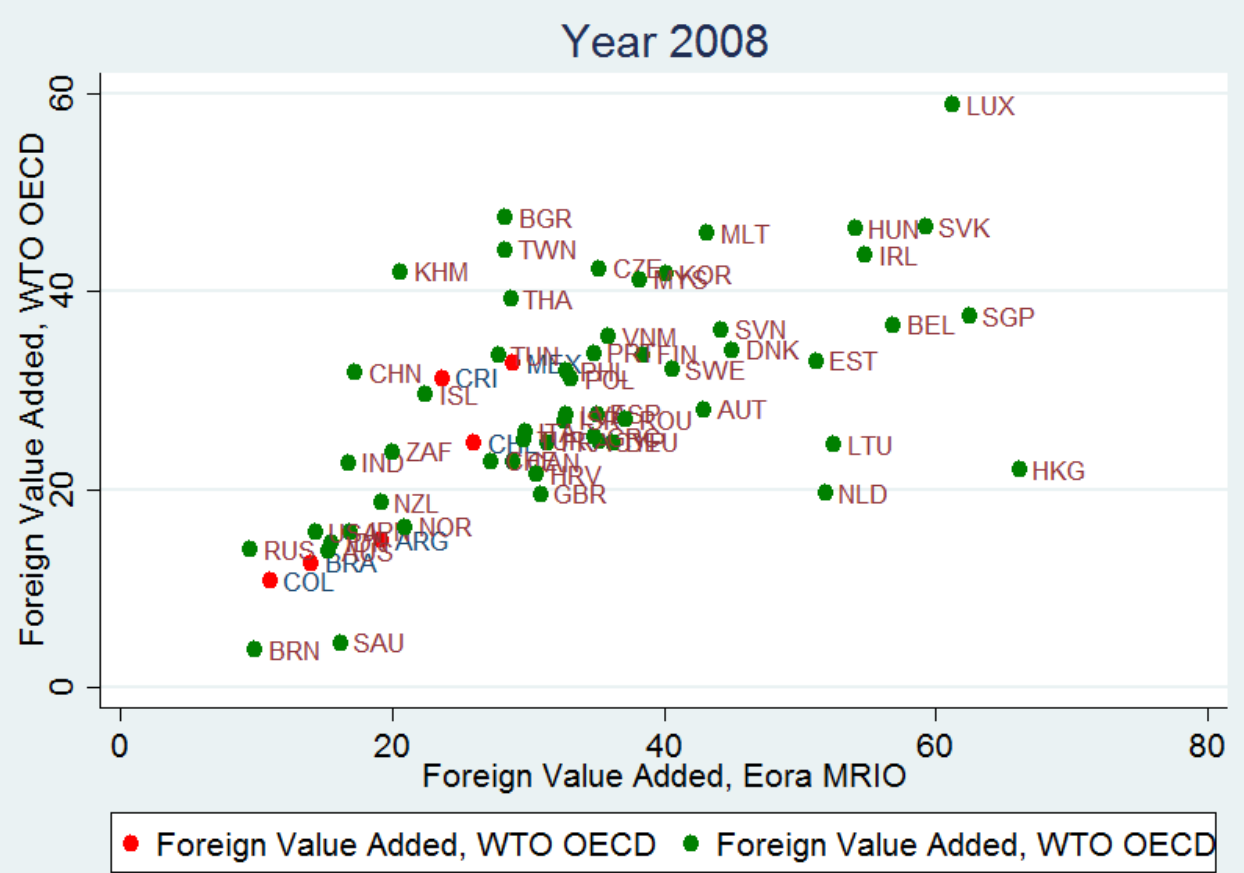

CInternational Monetary Fund. Not for Redistribution 
Figure 11: Comparing FVA from Eora and OECD-WTO Trade in Value-Added, 2009

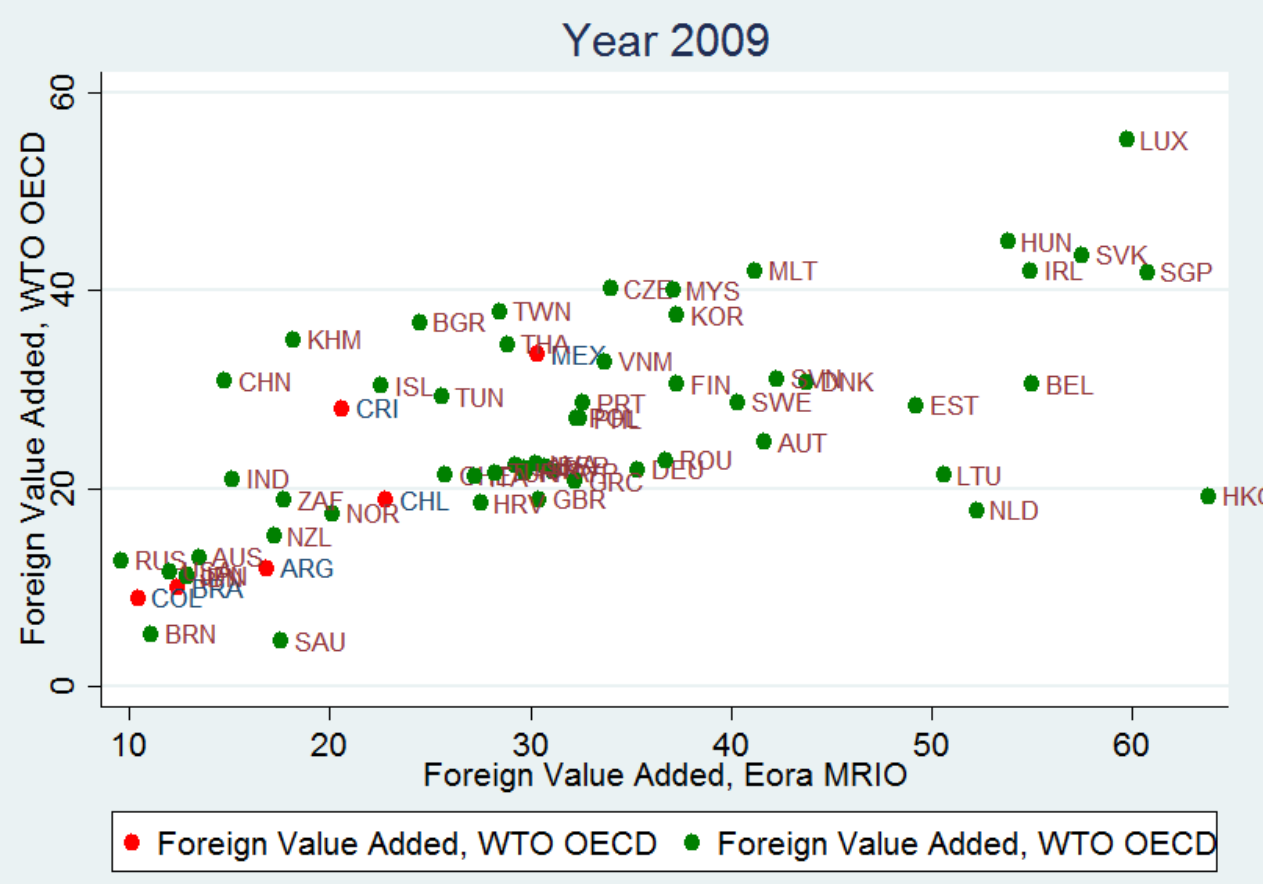

Figure 12: Comparing FVA from Eora and OECD-WTO Trade in Value-Added, 2010

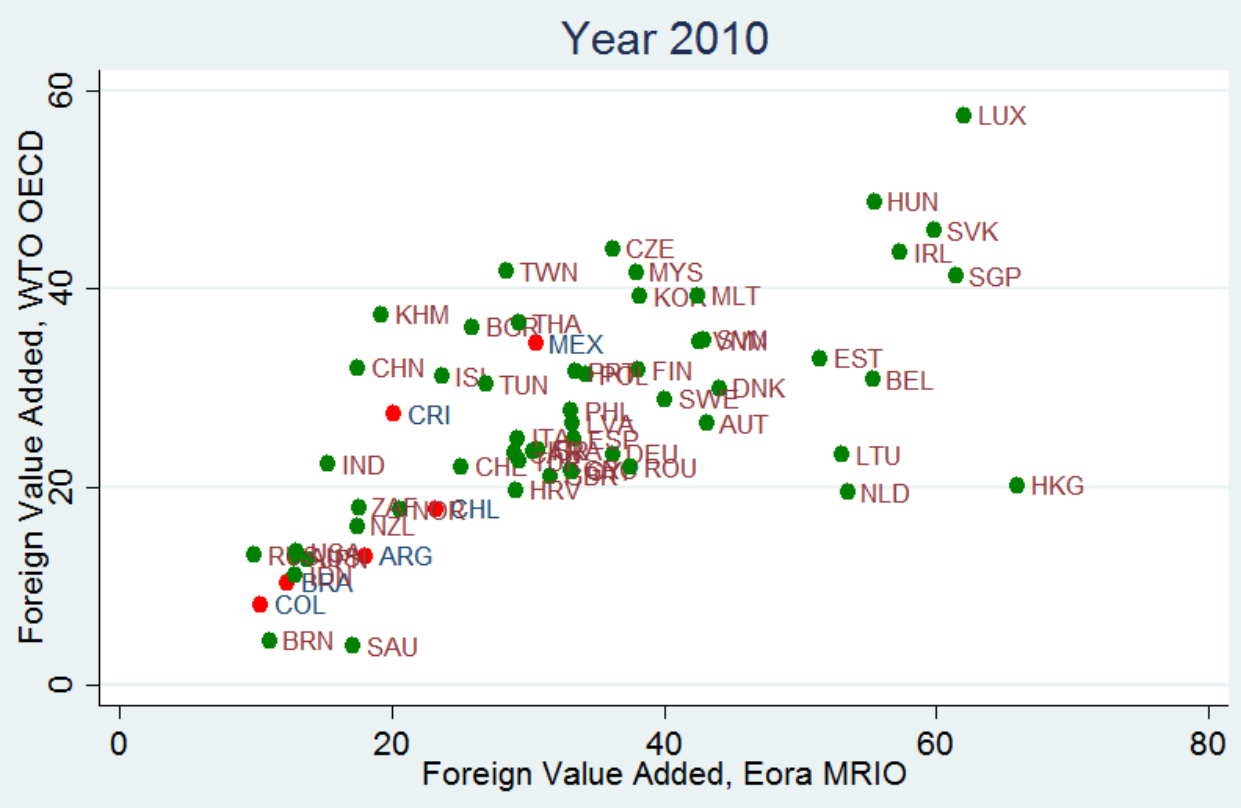

- Foreign Value Added, WTO OECD • Foreign Value Added, WTO OECD 
Figure 13: Comparing FVA from Eora and OECD-WTO Trade in Value-Added, 2011

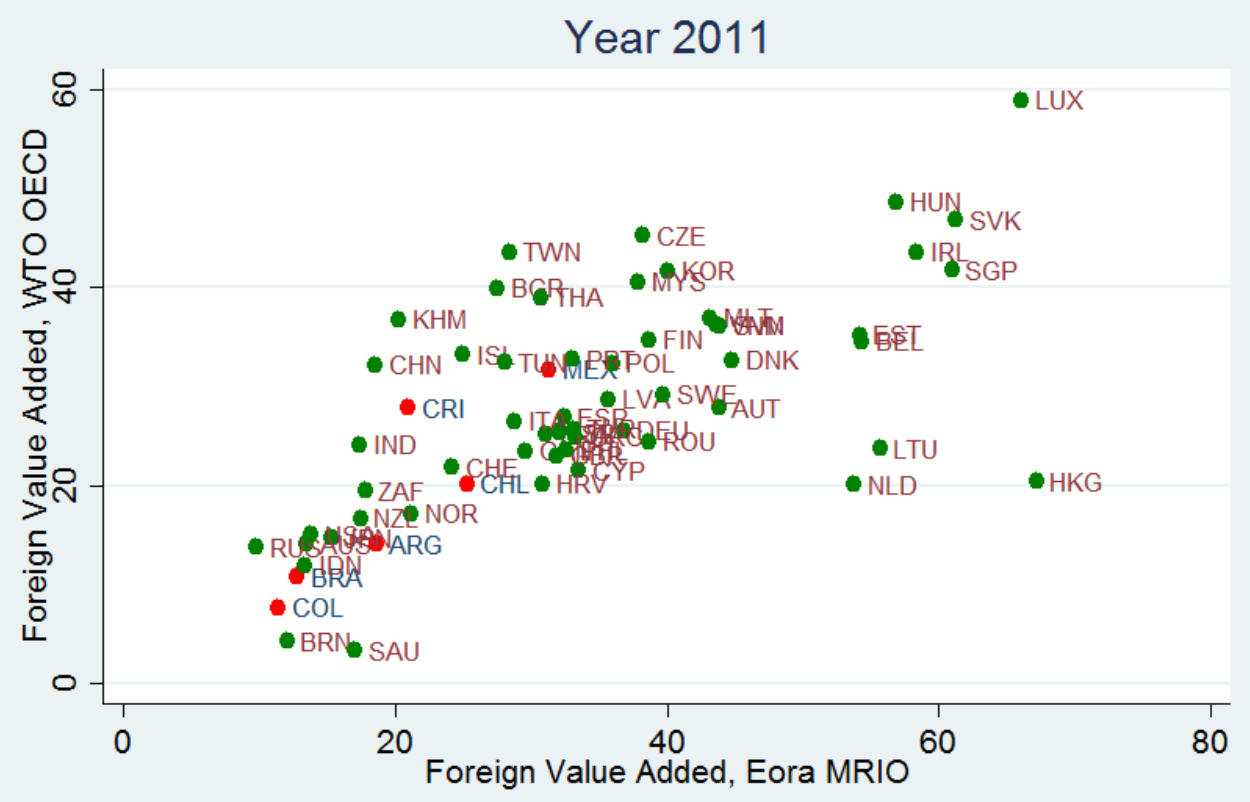

- Foreign Value Added, WTO OECD • Foreign Value Added, WTO OECD 


\section{References}

Borin, Alessandro, and Michele Mancini. 2015. "Follow the Value Added: Bilateral Gross Export Accounting." Bank of Italy Working Paper No. 1026, Bank of Italy, Rome, Italy.

Caliendo, Lorenzo, Robert C. Feenstra, John Romalis, and Alan M. Taylor. 2015. "Tariff reductions, entry, and welfare: Theory and evidence for the last two decades." NBER Working Paper No. 21768, National Bureau of Economic Research, Cambridge, MA.

Cerdeiro, Diego. A. 2016. "Estimating the Effects of the Trans-Pacific Partnership (TPP) on Latin America and the Caribbean (LAC)." IMF Working Paper No. 16/101, International Monetary Fund, Washington, DC.

Feenstra, Robert C. 2017. "Statistics to Measure Offshoring and its Impact." NBER Working Paper No. 23067, National Bureau of Economic Research, Cambridge, MA.

Haltmeier, Jane. 2015. "Have Global Value Chains Contributed to Global Imbalances?. International Finance Discussion Papers 1154, Board of Governors of the Federal Reserve System.

Hummels, David, Jun Ishii, and Kei-Mu Yi. 2001. "The Nature and Growth of Vertical Specialization in World Trade." Journal of International Economics 54(91): 75-96.

International Monetary Fund (IMF). 2015a. Chapter 3, Regional Economic Outlook: Subsaharan Africa, April, International Monetary Fund, Washington DC.

. 2015b. Chapter 4, Regional Economic Outlook: Western Hemisphere, October, International Monetary Fund, Washington DC.

2016a. Chapter 4, Regional Economic Outlook: Western Hemisphere, April, International Monetary Fund, Washington DC.

2016b. Chapter 2, World Economic Outlook, October, International Monetary Fund, Washington DC.

Johnson, Robert, and Guillermo Noguera. 2012. "Accounting for Intermediates: Production Sharing and Tarde in Value Added." Journal of International Economics 86(2): 224236.

Koopman, Robert, Zhi Wang, and Shang-Jin Wei. 2014. "Tracing Value-Added and Double Counting in Gross Exports.” American Economic Review 104(2): 459-494.

Koopman, Robert, William Powers, Zhi Wang, and Shang-Jin Wei. 2010. "Give Credit Where Credit Is Due: Tracing Value Added in Global Production Chains." NBER Working Paper No. 16426, National Bureau of Economic Research, Cambridge, MA. 
Lenzen, Manfred, Daniel Moran, Keiichiro Kanemoto, and Arne Geschke. 2012. "Mapping the Structure of the World Economy." Environmental Science \& Technology 46(15): 8374-8381.

Lenzen, Manfred, Daniel Moran, Keiichiro Kanemoto, and Arne Geschke. 2013. "Building Eora: A Global Multi-Region Input-Output Database at High Country and Sector Resolution." Economic Systems Research 25(1): 20-49.

Los, Bart, Marcel P. Timmer and Gaaitzen J. de Vries. 2016. "Tracing Value-Added and Double Counting in Gross Exports: Comment." American Economic Review 106(7): 1958-1966.

Tukker, Arnold, and Erik Dietzenbacher. 2013. "Global Multiregional Input-Output Frameworks: An Introduction and Outlook.” Economic Systems Research 25(1): 1-19.

United Nations Conference on Trade and Development (UNCTAD). 2013. "Global Value Chains and Development: Investment and Value Added Trade in the Global Economy." Advance Unedited Version. 